\title{
Modelling spatial distribution of epibenthic communities in the Gulf of St. Lawrence (Canada)
}

\author{
Charlotte Moritz $^{a, *}$, Mélanie Lévesque ${ }^{a}$, Dominique Gravel ${ }^{b}$, Sandrine Vaz $^{c}$, Diane Archambault ${ }^{d}$, \\ Philippe Archambault ${ }^{\mathrm{a}}$
}

\author{
a Institut des Sciences de la Mer, Université du Québec à Rimouski, 310, Allée des Ursulines, Rimouski, QC, \\ Canada G5L 3A1 \\ b Université du Québec à Rimouski, 300, Allée des Ursulines, C.P. 3300, Rimouski, QC, Canada G5L 3A1 \\ c IFREMER, French Res Inst Exploitat Sea, Channel and North Sea Fisheries Unit, 150 quai Gambetta, 62321, \\ Boulogne Sur Mer, France \\ ${ }^{\mathrm{d}}$ Institut Maurice Lamontagne, Fisheries and Oceans Canada, Mont-Joli, QC, CanadaG5H 3Z4 \\ *: Corresponding author : Charlotte Moritz, tel.: + $14187231986 x 1664$; fax: + 14187241842 ; \\ email address : c-m.moritz@laposte.net
}

\begin{abstract}
:
Correlative habitat models using relationships between marine organisms and their surrounding environment can be used to predict species distribution, and the results can assist management of human activities sharing the marine space (e.g. fisheries, MPAs, tourism). Here, epi-benthic megafauna was sampled at 755 stations in the Lower Estuary and Northern Gulf of St. Lawrence (EGSL) each summer between 2006 and 2009. We combined various types of multivariate analyses to 1) describe the structure and spatial distribution of benthic communities, 2) analyse the relationship between these communities and environmental parameters, and subsequently 3 ) build a community distribution model to predict the spatial distribution of the communities, creating community distribution maps covering the entire area to be used for marine management and conservation. We identified distinct benthic communities in the study area that closely correlate with the $200 \mathrm{~m}$ depth contour and with major environmental variables. A redundancy analysis revealed that communities were associated with depth, oxygen saturation, temperature, bottom current, seabed uniformity, distance to coast and type of sediment. Together these environmental descriptors explained $38 \%$ of the variation in megafaunal community composition. The environmental variables were used to build a community distribution model using generalized linear models to predict high and low suitability zones of each community in the EGSL.
\end{abstract}

\section{Highlights}

Epibenthic megafaunal communities of the Gulf of St. Lawrence were described. Their relationships with the environmental conditions were assessed. A statistical community distribution model was designed. Communities are strongly related to their environment. The different communities are predicted to live in specific habitats.

Keywords: Biodiversity ; Epibenthic Communities ; Estuary and Northern Gulf of St. Lawrence ; Generalized Linear Model ; Community Distribution Model ; Redundancy Analysis 
34

35

36

37

38

39

40

41

42

43

44

45

46

47

48

49

50

51

52

53

54

55

56

\section{INTRODUCTION}

Species distribution models (SDMs) are used to provide guidance for conservation planning, for instance during the process of designing protected areas, in a context of ecosystem-based management of natural areas. These models focus on the habitat characteristics surrounding the species. According to Baretta-Bekker et al. (1992), a habitat is simply the distinctive space occupied by a population or a species. The set of conditions required for an individual to survive and reproduce constitutes the "ecological niche" within which a species may indefinitely maintain itself (Hutchinson, 1957), and the geographical projection of this fundamental niche corresponds to the habitat of the considered species (Chase and Leibold, 2003). Therefore, a habitat is an area with specific environmental conditions in which an organism, a population, or a community can survive (e.g. Eastern

Channel Habitat Atlas for Marine Resource Management, Carpentier et al., 2009). In natural environments, most communities are associated with a recognisable suite of physical conditions, and some communities occur within a narrower physical habitat window than others (Urbanski and Szymelfenig, 2003). This relationship between physical characteristics of an area and biological composition of the associated communities can be assessed by

SDMs, which was initiated in terrestrial ecosystems several decades ago and is still developing (Degraer et al., 2008; Guisan and Zimmerman, 2000; Hirzel et al., 2006), in particular to study the possible consequences of a changing environment on species distributions (Guisan and Thuiller, 2005). In marine ecosystems more specifically, a large number of studies have demonstrated the importance of environmental factors as driving 
1995). From these analyses, full coverage spatial distribution maps of biological

communities or biodiversity can be created (Degraer et al., 2008, Mellin et al., 2010).

\begin{abstract}
Even though predicting species or community occurrence using modelling has become
\end{abstract} increasingly common in ecological conservation studies (Degraer et al., 2008; Martin et al., 2010, Mellin et al., 2012; Vaz et al., 2008), SDMs are often too simple scientifically speaking (they do not incorporate all ecological processes, Dormann et al., 2012) or too complex to be easily and safely transferred to decision makers and people responsible for natural-area management. With the higher number of management programs for marine space planning throughout the world, it is necessary to provide simple but accurate tools such as high-resolution easy-to-read present and future biodiversity distribution maps derived from SDMs to be used in environmental policies.

The Gulf of St. Lawrence (Canada) is a good candidate area in which to develop SDMs for marine ecosystem planning. Due to the variety of hydrodynamic regimes and physical processes observed, the Lower Estuary and Northern Gulf of St. Lawrence (EGSL) is often divided into distinct oceanographic sub-regions (Brunel et al., 1998; Koutitonsky and Bugden, 1991). This high spatial heterogeneity is combined with high faunal diversity, which make the EGSL a good area to evaluate the potential connections between 74 environmental factors and marine communities. Notwithstanding a limited number of local 75 or taxon-specific studies investigating diversity and distribution of benthic invertebrates 76 (Belley et al., 2010; Bourque, 2008; Desrosiers et al., 2000; Massad and Brunel, 1979; 77 Ouellet, 1982; Peer, 1963, Préfontaine and Brunel, 1962; Robert, 1979), benthic communities at the EGSL scale remain poorly understood. Additionally, some of the ESGL 79 oceanographic conditions have already noticeably changed due to global climate change 
(modification of water layer heights and increased hypoxia: Belley et al., 2010; Gilbert et al., 2005, 2007; acidification, Mucci et al., 2011), which generates a strong need for tools to predict present and future biodiversity distribution and aid conservation management.

Because of the presence of several diversity conservation and fishery issues (such as fishery overlap or stock management, DFO, 2006, 2010), fishery managers, governmental organisations, and research institutes are working together to gather new methods and tools to predict species distribution and community structure (e.g. Canadian Fisheries Research Network: http://www.cfrn-rcrp.ca), and could therefore benefit directly from this study. been conducting annual groundfish and northern shrimp bottom trawl surveys in the EGSL. The main objective was to collect biological information related to commercially important groundfish (cod, Greenland halibut, redfish) and northern shrimp stocks exploited in the EGSL. Each summer 2006 to 2009, the effort was intensified for the identification of all benthic invertebrate taxa aboard the CCGS Teleost research trawler. In spite of this intensive sampling effort, the relative opacity of seawaters renders species community observation on a continuous large area impossible. In this case, community distribution models (CDMs) can be implemented to give a better picture of community composition in poorly-sampled areas of the EGSL. Given that correlations between environmental conditions and species distribution are known to exist, we assume that such relationships will also be detectable at the community level. We therefore hypothesise that temperature, depth, and oxygen will be strong determinants of community structure. Sediment type and other hydrodynamic-related variables are expected to have a weaker influence on community structure. The 2006-2009 dataset was therefore used to: (1) explore the composition and distribution of the epibenthic 
103

104

105

106

107

108

109

110

111

112

113

114

115

116

117

118

119

120

121

122

123

124

125

megafaunal community using multivariate analyses; (2) correlate the communities' spatial

distribution with the abiotic factors to determine which environmental parameters may drive diversity patterns; and (3) create high-resolution maps from a statistical CDM, describing megafaunal community affinities with significant environmental parameters.

\section{MATERIAL AND METHODS}

\subsection{Study area}

The EGSL has two major connections with the Atlantic Ocean, through Cabot and Belle-Isle Straits, and receives important freshwater inflows, mainly from the St. Lawrence River. Consequently, estuarine circulation occurs by water flowing seaward in the surface layer and landward in the deep layers (Saucier et al., 2003). The topography of the northern part of the Gulf is distinguished by three deep channels: Laurentian, Anticosti, and Esquiman (Fig. 1).

\subsection{Survey method and biological data collection}

Megafauna was sampled from 755 stations in total during summers 2006 to 2009 (131 August each year), with sampling station depth spanning from 24 to $512 \mathrm{~m}$, and minimal distance between two stations being $115 \mathrm{~m}$ (Fig.1). The sampling strategy used consisted of a stratified random sampling following predetermined strata based on depth (Doubleday, 1981). All samples were collected with a four-sided shrimp bottom trawl (Campelen 1800 type). The trawl was rigged with variable net mesh sizes (44 to $80 \mathrm{~mm}$ centre knot to centre knot) appropriate for each part of the trawl. The codend and the lengthening piece were also equipped with a $12.7 \mathrm{~mm}$ knotless nylon lining (McCallum and Walsh, 2002). The standard tow duration was 15 minutes on the bottom but was shorter in rare cases where the substrate 
126

127

128

129

130

131

132

133

and tows below this threshold were removed (Archambault et al., 2012). The 15-minute duration was then used to calculate the biomass for all tows.

The catch from scientific surveys was sorted and identified to the lowest possible taxonomic level. Because colonial organisms such as bryozoans and hydrozoans were too abundant to be enumerated, the wet weight of each taxon was instead recorded. The sorted megafauna was photographed aboard, and images of total capture and of each identified taxon were recorded. Species not identified while at sea were preserved in $70 \%$ ethanol or frozen for later identification in the laboratory. Taxonomic names were verified using the Integrated Taxonomic Information System (www.itis.gov). Biomass estimates were standardized relative to catch per unit effort (CPUE) by dividing the mass of a taxon by the total area swept by the trawl. Biomasses in the database were therefore expressed in $\mathrm{kg} \cdot \mathrm{km}^{-2}$.

\subsection{Environmental variables and spatial distribution maps}

Two sets of environmental variables characterizing the EGSL were gathered from different sources, i.e. at the sampling stations and throughout the EGSL.

At each sampling station, a CTD Seabird ${ }^{\mathrm{TM}}$ apparatus (SBE911 Plus), combined with a SBE 43 dissolved oxygen sensor, measured the water column characteristics such as salinity (conductivity), temperature, and dissolved oxygen at predetermined depths, including the bottom. Titrations of water samples, collected with Niskin bottles fixed on a rosette, were carried out to corroborate the concentration of dissolved oxygen measured with the oxygen sensor. Geographical (e.g. distance to coast) and physical descriptors related to the underwater relief were also gathered for each sampling station (Dutil et al., 2011). Another extensive set of these water-column, geographic, and physical data, located all over the EGSL, was used (Dutil et al., 2011). Bottom current, included as an abiotic factor in the 
149 environmental dataset, was obtained using a three-dimensional coastal ice-ocean model with

150 realistic tidal, atmospheric, hydrologic and oceanic forcing (Saucier et al., 2003). At each

151 sampling station, the maximum mean hourly bottom current value in $\mathrm{cm} . \mathrm{s}^{-1}$ was obtained for

152 August for each corresponding year (2006 to 2009), and, for the entire EGSL, maximal

153 values per year, averaged over 2006 to 2009, were calculated and included in the EGSL

154 environmental dataset. A digital map of seabed sediment types, derived from Loring and

155 Nota (1973) and validated using sediment grabs by Bourque (2008) and pictures of the

156 seafloor from Belley et al. (2010), was used to determine substratum type in the entire EGSL,

157 including at each sampling station. The original sediment classification contained 46

158 substratum codes identified by textual analysis, and, for simplification, 14 groups were made 159 from these and retained for subsequent analysis (Table 1).

160 Continuous raster maps of the main environmental variables were produced (Fig. A.1).

161 Interpolated values using kriging of the initial variables covering the entire EGSL were

162 estimated on a fine regular grid of points on ArcMap (version 9.1, ESRI, Inc), and the Spatial

163 Analyst extension was used to illustrate continuous spatial patterns of each variable.

164

165

166

167

\subsection{Statistical analysis and modelling framework}

A step-by-step set of analysis was used to understand the structure of epibenthic communities in the EGSL and predict their presence according to the surrounding environmental conditions: communities and the environment were first described separately using clustering and multivariate analysis, then the relationships between communities and the environment were determined using multivariate analysis. Finally, generalized linear models were used to predict habitat suitability, i.e. the probability of presence, of the communities in the EGSL. Data were analysed using the vegan library (Oksanen, 2011) in 
172 the statistical package R version 2.14.1 (R Development Core Team, 2011). Prior to analyses,

1736 taxa (out of 221) that appeared only once were excluded from the analyses, as suggested by

174 Clarke and Warwick (1994).

175 2.5. Analysis of epibenthic communities, the environment, and relationships between

176 communities and the environment.

177 Bray-Curtis dissimilarity measure (Bray and Curtis, 1957) was used to build a

178 community dissimilarity matrix, in order to define distinct communities from the co-

179 distributions of individual species. The dissimilarity matrix was then subjected to a

180 hierarchical cluster analysis using Ward's minimum variance agglomeration method to detect

181 compact, spherical clusters (Ward, 1963). A number of well-defined clusters corresponding

182 to dissimilarity between communities of less than $20 \%$ was selected. Each cluster

183 corresponded therefore to a group of stations, and each group hosted one community. Non-

184 metric multidimensional scaling (nMDS) ordination, based on the Euclidean distance on

185 Hellinger-standardized biomass data (Legendre and Gallagher, 2001) was carried out to

186 visualise the position of the clusters on the ordination diagram with minimum stress.

187 Geographical distribution of these communities in the Gulf was then mapped using ArcGIS

188 software (version 9.1, ESRI, Inc.).

189 Because many environmental variables were available (Table 1), a variable-reduction

190 procedure was carried out to select a subset of environmental variables that minimized

191 collinearity. A principal component analysis (PCA) was combined to an analysis of the

192 correlation matrix to select one or two environmental variables per group of multicollinear

193 variables. The relationship between epibenthic community composition (i.e. each group of

194 station) and the selected environmental variables was then evaluated using a multivariate 
195

196

197

198

199

200

201

202

203

204

205

206

207

208

209

210

211

212

213

214

215

216

217

method of constrained linear ordination, the redundancy analysis (RDA, Legendre and Legendre, 1998). This method seeks the linear combination of explanatory (i.e.

environmental) variables that best explain the variation of the biological community matrix.

In RDA, species scores correspond to strength and direction of correlation of the species with a particular factor. RDA was performed on Hellinger-standardized data to avoid rare species and sites with many individuals to have a differential weighting (Legendre and Gallagher, 2001). To assess which environmental factors are most important to explain RDA axes, a permutation test (999 permutations) was used to test correlations between the stations and the variables on the first and second RDA axes. This allowed assessing the statistical significance of the relationship between the communities found at each station with respect to the environmental variables.

\subsection{Community distribution model (CDM)}

The suitability of habitat for biological communities can be evaluated from the available knowledge on the optimal range of abiotic conditions for megafaunal species. To link the presence of a given community with respect to the local environmental conditions in the EGSL, generalized linear models (GLM, McCullagh and Nedler, 1989) were applied to each community. The presence-absence of a given community at each station was used as the response variable, and the environmental variables used in the RDA were used as predictors, assuming a binomial distribution with a logit-link function.

To make predictions at the scale of the whole EGSL, only the significant variables retained for each community were included in a second set of GLMs. The resulting community-specific estimates were gathered and included in the inverse of the logit function along with the standardized environmental data covering the entire EGSL. The values 
218 obtained represent the probability of presence, or habitat suitability, of each community in the

219 EGSL. Statistical tests using Moran's I were performed to check for spatial autocorrelation of 220 model residuals. Continuous raster maps of presence probabilities were then drawn using the 221 Spatial Analyst extension in ArcMap (version 9.1, ESRI, Inc).

222 3. RESULTS

223 3.1. Epibenthic community structure

224 Cluster analysis based on Bray-Curtis dissimilarity of biomass data highlights six 225 groups or communities (Fig. 2a) that cluster on an MDS graph (stress $=0.16$, Fig. 2b). These 226 communities are located in distinct regions of the EGSL (Fig. 3). The 6 groups are composed 227 of almost the same dominant species in terms of biomass (Table 2). A SIMPER analysis 228 (results not shown) revealed that these species are also responsible for the differences 229 between the groups, indicating that it is a specific set of several species and their respective 230 abundance that are discriminant of community dissimilarity, rather than a single 231 intermediate-abundance species for each community.

232 The largest and most diverse group (group A, Table 2) is found along the coasts, i.e. in 233 the Estuary, around Anticosti Island and along most of the eastern side of the Gulf (western 234 part of Newfoundland) up to the Strait of Belle Isle (Fig. 3A). This community is composed 235 of sessile filter-feeder anemones (e.g. from order Actiniaria and phylum Cnidaria), mobile 236 deposit-feeder Echinoderms (e.g. Ophiura sp., Ctenodiscus crispatus, Strongylocentrotus sp., 237 Gorgonocephalus sp.), and prawns Pandalus montagui (adapted to cold shallow waters) and, 238 to a lesser extent, Pandalus borealis. These organisms make up a large part of the total 239 biomass of the group (Table 2). This group is also characterised by the presence of the sea 240 star Crossaster papposus, frequent in coarse sediment characterising stations in this group 
and usually feeding on Strongylocentrotus urchins, and of Rhachotropis aculeata (from suborder Gammaridea and order Amphipoda), which occurs only in one station of other groups.

Group B, comprising the fewest number of species among all groups (Table 2), is almost exclusively located in the upper part of the Laurentian Channel, i.e. in the Estuary (Fig 3B). Like in its neighbouring communities of group A, biomass is dominated by Actiniaria and the prawn species $P$. montagui (Table 2), but the compositional structure of the dominant echinoderms differs from group A (e.g. Brisaster fragilis, Ophiura sarsi, Hippasteria phrygiana). Pennatulacea and Pasiphaea multidentata (a caridean shrimp), adapted to great depths, are also abundant in this group.

Groups C, E and F are located in the deep channels (Laurentian, Anticosti, Esquiman) and mostly in the wider part outside of the Estuary, following a north-south gradient (group E in the north, group $\mathrm{F}$ in the centre, and group $\mathrm{C}$ in the south out to the Atlantic Ocean that begins at Cabot Strait: Fig. 3C, E, F). These groups were characterised by high occurrences of anthozoans such as Actiniaria (sea anemones) and Pennatulacea (sea pens) (Table 2), and two echinoderm species (Ctenodiscus crispatus and Brisaster fragilis).

Finally, many stations hosting group D are located on channel edges, where the community is composed of organisms adapted to depth and slope, such as Actiniaria and Porifera, and, like groups C, E and F, Pennatulacea, Gorgonocephalus sp, C. crispatus and B. fragilis. Group D, characterised by many stations of medium depth, also comprises high biomass of both prawn species $P$. borealis (adapted to deeper and warmer waters) and $P$. montagui. The relative importance of these two species in this group is opposite to that of group A (Table 2) due to the difference of depth and water temperature. 


\subsection{Relationship between communities and their environment}

The RDA biplot displays the correlation of the environmental factors (depth, bottom temperature, bottom-water oxygen saturation, maximal bottom current, relief, geographic variables, and sediment types) with epibenthic communities on the first two dimensions of the ordination (Fig. 4). Among the environmental variables considered, only slope and surface of sheltered area are not significantly correlated to the communities (Table 3).

Temperature, depth, distance to coast and seabed uniformity are positively correlated with the first RDA axis. Oxygen saturation and bottom current are inversely correlated with these

factors and with the first RDA axis, indicating that low oxygen values and slow bottom currents correspond with deeper and warmer waters, further from the coast. Some coarse substratum types $(2,2 \mathrm{c}, 2 \mathrm{~d}, 2 \mathrm{e}, 5$, and, to a lesser extent, 3 and 4$)$ are located along the first RDA axis, whereas finer substratum types (fine sand: $2 a$ and $2 b$, and sandy pelite $1 \mathrm{e}$ ), some of the main substratum compositional types found in the EGSL, are correlated with the second axis.

The RDA explains $38 \%$ of the variance in species biomass. Together, the first and second principal RDA axes account for $81 \%$ of the relationship between species and environmental parameters (first axis: $68 \%$, and second axis: $13 \%$ of the total variation, Table 3). The arrangement of samples on the RDA biplot in relation to the environmental parameters shows two main aggregates. Stations hosting group A (Fig. 4, graph left handside) are strongly correlated with high oxygen saturation, strong bottom current, shallower cooler waters closer to the coast with coarse sediments. Conversely, stations on the right handside

(Fig. 4: groups D to F and most stations of groups B and C) are more closely associated with deeper warmer waters with low oxygen saturation, weak current and fine sediments (except 5: ice-age rocks). Group B is found in the Estuary, which is characterised by medium to high 
Spatial distribution of benthic communities

287 depths and low oxygen saturation (Fig. 1A), and thus located on the lower part of the graph

288 on both side of the second RDA axis. Groups D, E and F, found in the rest of the Gulf at

289 different depths (Fig 4D, E, F), cluster on the upper part of the graph. Group C is spread

290 along the second RDA axis, mainly on the right side of the ordination plan, indicating a high

291 variability of the environmental conditions within this niche: stations representing this group

292 are found at different values of depth, temperature, and on different types of sediment.

\section{3.3. Community distribution model}

294 The coefficients of the GLM models show that the presence of each group A to F is 295 correlated with different significant environmental variables (Table 4). The habitat suitability 296 maps projected by the GLMs highlight the areas of high probability of presence for each 297 group (Fig. 5). Group A, retaining predictors of depth, oxygen saturation and coarse 298 sediment, has high probabilities to occur along the coast, at shallow depths and on coarse299 grain bottoms, especially along the north coast and around Anticosti Island (Fig. 5A).

300 Temperature and oxygen saturation characterise groups B, D, E and F, which have 301 comparable distribution patterns, i.e. mainly in deep channels (Fig. 5B, D, E, F). However, 302 group B was previously found only in the Estuary where oxygen saturation is low (Fig. 3B), 303 but the habitat suitability map indicates that this group can be found in other parts of the 304 EGSL that have similar environmental characteristics. Group D is characterised by 3 different 305 types of pelitic sediments, which explains why it occurs outside of the deep channels: species 306 composing this group are adapted to live on different substrates (Fig. 5D). Group C, 307 characterised by slope, is predicted to occur at moderate depth, on the edge of the deep 308 channels (Fig. 5C). It is characterised by a complex set of environmental variables (Table 4), 309 which indicates that several conditions have to be fulfilled for the species composing this 310 community to live in there. Moderate to high habitat suitability for groups $\mathrm{E}$ and $\mathrm{F}$ are 
Spatial distribution of benthic communities

311 strongly associated with sediment (calcareous pelite for both $\mathrm{E}$ and F, pelitic sand for F)

312 found in deep channels, especially in the Laurentian channel (Fig. 5E, F). Despite the fact

313 that it was a significant variable in explaining overall EGSL community distribution (Fig. 4),

314 bottom current was not retained as a predictor to estimate the localisation of any of the 315 groups. No spatial autocorrelation of model residuals was found when using Moran's I for

316 regression residuals (not shown), except for GLM of group F which residuals display a low 317 but slightly significant spatial autocorrelation (Moran' $I=0.06, p=0.04$ ). Models A to E 318 show overall good performance (AUC $\geq 0.8$, Table 4); only model F performs slightly less $319 \quad(\mathrm{AUC}=0.77)$. 2007; Lévesque, 2009). We found distinct megafaunal communities that occupy different

\section{DISCUSSION}

\subsection{Community distribution and the role of environmental variables.}

The environment of the EGSL is spatially structured, which in turn affects biological community structure. Communities determined in this study are strongly correlated with their environment, which is in good agreement with preliminary studies investigating the distribution of macro- and megafaunal benthos in the Gulf of St. Lawrence (Chabot et al., habitats, especially in the deep channels vs shallower areas, and from estuarine to more marine areas. The RDA revealed the ecological preference of species colonizing the study habitats by identifying the environmental variables strongly correlated with epibenthic community distribution. The $38 \%$ of variation explained is in the range of values for biological systems (Cottenie, 2005). No single variable appeared to be directly and 334 whereas oxygen saturation and bottom current were inversely correlated with these variables, 
in agreement with Chouinard and Dutil (2011). Coarse substratum found mainly along the coastlines can generate a range of diverse well-oxygenated habitats favouring biological organisms, which is why these areas were associated to the highest predicted suitability for the shallow-water community.

In past studies, substrate granulometry and associated biological and chemical factors operating over the long term (e.g. organic content and microbial biomass of the sediment:

Gaston, 1987; Maurer and Leathem, 1981) were considered as important environmental factors explaining spatial patterns of benthic organisms (Labrune et al. 2007, 2008; Thorson, 1971). Another study carried out in the Southern North Sea showed the importance of bed shear stress on benthic community distribution (Vaz et al., 2007). In fact, bottom current is responsible for bed shear stress that reflects the friction pressure found on the seabed and affects sediment sorting, thus sediment particle size (Harris and Wiberg, 2002). Our CDMs showed that megafaunal community groups (except group B) were correlated with composition of pelite, sand, or gravel, rather than with bottom current, suggesting that the effects of hydrodynamics (here, bottom current influencing particle mobility and sediment stability: Newell et al., 1998) on community structure may be concealed behind the effects of sediment properties.

Several sub-communities from group A, B, C, and D were defined in regions where specific environmental conditions and hydrodynamic features such as upwelling and tidalmixing are located. This explains why bottom current was one of the variables retained by the RDA to explain community structure. More specifically, the Northwest Gulf community defined by Sainte-Marie et al. (2005), adjacent to the Mingan Islands (north-east coast) and the Strait of Belle-Isle (corresponding to communities of group A in this study), is located in 
an area of the EGSL with major circulation features, such as strong tidal-mixing and wind-

359 induced coastal upwelling and eddies (Le Fouest, 2005). Similarly, a productive zone of

upwelling arises from the bottom topography and wind interaction in the western Strait of Belle-Isle (Rose and Legett, 1988). The mixing of Labrador Shelf waters that enter via the Strait of Belle-Isle into the Gulf (Houghton and Fairbanks, 2001) and waters from the rest of the Gulf could favour highly diverse benthic communities. Frontal and high bottom current areas are known to be very productive and support high species diversity because the wider range of environmental values associated to these water layers create a combination of several distinct suitable habitats (e.g. deep-sea, Thistle et al., 1985; pelagic plume front, Josefson and Conley, 1997). This high diversity may include ecosystem-engineer species (both within mega-, macro- or meiofauna) that could also increase habitat complexity and create new additional niches for epifauna (Rabaut et al., 2007).

The distinctiveness of the estuarine community group B may arise because of specific environmental conditions found in this part of the Estuary, compared to more marine areas of the Gulf, such as low salinity (due to arrival of freshwater), poor oxygen saturation, and turbidity (Belley et al., 2010). The boundaries of this community also fitted closely to the bathymetric morphology of the Laurentian Channel. However, the CDMs did predict high probabilities of occurrence of group B in all deep channels, indicating that the environment may be suitable for this community (potential ecological niche), if the species were to migrate to these habitats due to fishery or global change pressure for instance. Similar bathymetry-related community patterns, formed by some stations from groups $\mathrm{C}$ to $\mathrm{F}$, were found in the Laurentian, Anticosti and Esquiman Channels and edges (“deep-channel community": > $200 \mathrm{~m})$. 


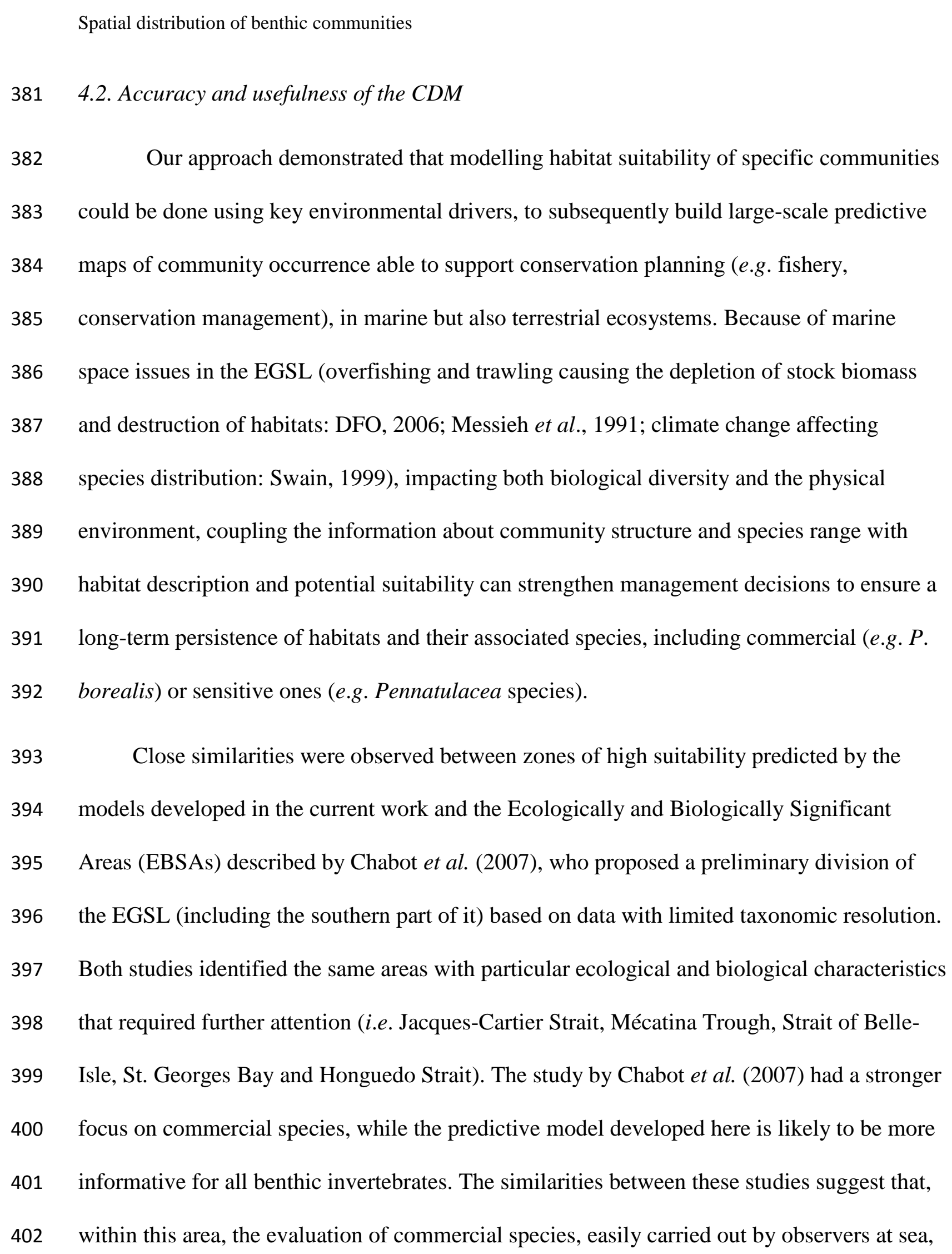

\subsection{Accuracy and usefulness of the CDM}

399 Isle, St. Georges Bay and Honguedo Strait). The study by Chabot et al. (2007) had a stronger

400 focus on commercial species, while the predictive model developed here is likely to be more 401 informative for all benthic invertebrates. The similarities between these studies suggest that, 402

could be done using key environmental drivers, to subsequently build large-scale predictive maps of community occurrence able to support conservation planning (e.g. fishery, conservation management), in marine but also terrestrial ecosystems. Because of marine space issues in the EGSL (overfishing and trawling causing the depletion of stock biomass and destruction of habitats: DFO, 2006; Messieh et al., 1991; climate change affecting species distribution: Swain, 1999), impacting both biological diversity and the physical environment, coupling the information about community structure and species range with habitat description and potential suitability can strengthen management decisions to ensure a long-term persistence of habitats and their associated species, including commercial (e.g. P. borealis) or sensitive ones (e.g. Pennatulacea species).

Close similarities were observed between zones of high suitability predicted by the models developed in the current work and the Ecologically and Biologically Significant Areas (EBSAs) described by Chabot et al. (2007), who proposed a preliminary division of the EGSL (including the southern part of it) based on data with limited taxonomic resolution. Both studies identified the same areas with particular ecological and biological characteristics that required further attention (i.e. Jacques-Cartier Strait, Mécatina Trough, Strait of Bellewithin this area, the evaluation of commercial species, easily carried out by observers at sea, 
may be used as a proxy for describing variation in the ensemble of benthic megafaunal

404 communities.

405 Our model provides a coherent picture of the distribution of megafaunal benthic 406 invertebrates in the Gulf, but increasing efforts to obtain more accurate environmental and 407 biological data throughout the years would lead to model improvement and validation. All 408 available environmental predictors known to be influential on marine communities were 409 considered in this study. We however acknowledge that other yet unavailable predictors 410 could be considered (e.g. nutrients: Mellin et al., 2010; fishing effort: Mellin et al., 2012;

411 sediment organic matter and porosity, Chl a: Pastor et al., 2011) in order to better understand 412 benthic community structure, and improve elaboration and predictive power of CDMs.

413 Biological data from other surveys using a different sampling method or in shallow near414 shore locations (i.e. extending depth coverage to $25 \mathrm{~m}$ deep or above) and data gathered by 415 the Canadian fishing industry could also be homogenised and incorporated, and used for 416 validation and model transferability assessment to improve model accuracy and selection 417 (Wenger and Olden, 2012). Indeed, the main database used here is updated annually by DFO 418 through multispecies surveys and complementary efforts to monitor benthic habitat quality.

419 In a further step, the effects of fishing activities on benthic habitats could also be investigated 420 in the model by including information on spatial and temporal variation in fishing effort, to

421 complete goals to be reached to evaluate the impact of fishing activities on benthic organisms 422 in the Gulf of St. Lawrence (DFO 2006, 2010).

\section{5. CONCLUSION}

424 This study demonstrates the usefulness of a CDM elaborated from data 425 (environmental observations and bottom trawl samples gathered during annual scientific 
surveys) to infer relationships between environmental variables and specific benthic

communities. The predicted habitat suitability distribution obtained is composed of

preliminary informative maps onto which additional physical and chemical parameters could

429 be added to better delineate habitat suitability of each community. Biological organisms will

430 react to natural and anthropogenic changes currently occurring in natural systems and may

431 change their distributions accordingly. Distribution models may thus be used to improve

432 predictions of the distribution change of key and indicator species and particular

433 communities, and to identify potential diversity hot spots, by focusing on current and stable

434 versus future and changing environmental conditions, with limited information on biological 435 communities.

436 Within large networks of ocean and land planning gathering different actors, the aim 437 of CDM is to help scientists and decision-makers to elaborate guidelines and priorities for 438 adequate conservation of habitats hosting specific communities, and that take into account 439 future biological community range changes. In the EGSL, these communities support highly 440 valuable commercial species (e.g. prawn $P$. borealis), which stock sustainability must be 441 secured. Informed conservation decisions will in turn ensure appropriate monitoring of the 442 spatial and temporal quality of benthic habitats, which could help minimize or avoid impact 443 of natural and anthropogenic disturbances.

\section{ACKNOWLEDGEMENTS}

CM received funding from Fonds Québécois de Recherche Nature et Technologie, 446 Réseau Aquaculture Québec, and Natural Sciences and Engineering Research Council of 447 Canada through the Canadian Fisheries Research Network. Part of this work was conducted 448 in partial fulfilment of the requirements for M. Lévesque of a Master's degree (Université du 449 Québec à Rimouski), supervised by P. Archambault and D. Archambault. We wish to 
acknowledge the collaboration framework set between Ifremer and DFO, which greatly stimulated methodological exchanges between the different authors. We are grateful to Pierre-Marc Chouinard (Institut Maurice Lamontagne, DFO) and Virignie Roy (ISMER Université du Québec à Rimouski) for fruitful discussions on statistical analysis, to Timothée Poisot (Université du Québec à Rimouski) and Camille Mellin (AIMS, Australia) for useful advice in R, and to Hedvig Nenzen (Université du Québec à Rimouski) for text editing. We are also indebted to Simon Senneville, Simon St-Onge Drouin, Jean-Guy Nistad, Jean-Denis Dutil and Serge Proulx for providing environmental data. Finally, we thank the anonymous reviewers for their constructive comments.

\section{REFERENCES}

Archambault, D., Bourdages, H., Bernier, B., Fréchet, A., Gauthier, J., Grégoire, F., Lambert, J. and Savard, L., 2012. Preliminary results from the groundfish and shrimp multidisciplinary survey in August 2011 in the Estuary and northern Gulf of St. Lawrence. DFO Can. Sci. Advis. Sec. Res. Doc. 2011/112.

Baretta-Bekker, J. G., Dunnrsma, E. K., Kuipers, B. R., 1992. Encyclopedia of Marine Sciences. Berlin: Spinger.

Belley, R., Archambault, P., Sundby, B., F. Gilbert, Gagnon, J.-M., 2010. Effect of hypoxia on benthic macrofauna and bioturbation in the Estuary and Gulf of St. Lawrence, Canada. Continental Shelf Research 30, 1302-1313.

Bourque, M., 2008. Variabilité spatio-temporelle de la macrofaune endobenthique profonde du Saint-Laurent (Québec, Canada) au cours d'un évènement hypoxique. Master's thesis, Université du Québec à Rimouski, Rimouski (Québec).

Bray, J. R., Curtis, J. T., 1957. An ordination of the upland forest of Southern Wisconsin. 
473

474 Brunel, P., Bossé, L., Lamarche G., 1998. Catalogue des invertébrés marins de l'estuaire et 475 du golfe du Saint-Laurent. Publication Spéciale Canadienne des Sciences Halieutiques et 476 Aquatiques 126, $405 \mathrm{pp}$.

Ecol. Monograph. 27, 225-349.

477 Carpentier, A., Martin, C.S., Vaz, S., 2009. Channel Habitat Atlas for marine Resource 478 Management, final report / Atlas des habitats des ressources marines de la Manche orientale, 479 rapport final (CHARM phase II). INTERREG 3a Programme, IFREMER, Boulogne-sur-mer, 480 France.

481 Carassou, L., Ponton, D., Mellin, C., Galzin, R., 2008. Predicting the structure of larval fish 482 assemblages by a hierarchical classification of meteorological and water column forcing 483 factors. Coral Reefs 27, 867-880.

484 Chabot, D., Rondeau, A., Sainte-Marie, B., Savard, L., Surette, T., Archambault, P., 2007. 485 Distribution des invertébrés benthiques dans l'estuaire et le golfe du Saint-Laurent. $D F O$ 486 Can. Sci. Advis. Sec. Res. Doc. 2007/018.

487 Chase, J.M., Leibold, M.A., 2003. Ecological niches. University of Chicago Press, Chicago, 488 IL.

489 Chouinard, P.-M., Dutil, J.-D., 2011. The structure of demersal fish assemblages in a cold, 490 highly stratified environment. ICES J. Mar. Sci. 68, 1896-1908.

491 Clarke, K.R., Warwick, R. M., 1994. Similarity-based testing for community pattern: the 492 two-way layout with no replication. Mar. Biol. 118, 167-176.

493 Cottenie, K., 2005. Integrating environmental and spatial processes in ecological community 494 dynamics. Ecol. Lett. 8, 1175-1182. 
495 Degraer, S., Verfaillie, E., Willems, W., Adriaens, E., Vincx, M., Lancker, V., 2008. Habitat 496 suitability modelling as a mapping tool for macrobenthic communities: An example from the 497 Belgian part of the North Sea. Cont. Shelf Res. 28, 369-379.

498 Desrosiers, G., Savenkoff, C., Olivier, M., Stora, G., Juniper, K., Caron, A., Gagné, J.-P., 499 Legendre, L., Mulsow, S., Grant, J., Roy, S., Grehan, A., Scaps, P., Silverberg, N., Klein, B., 500 Tremblay, J.-E., Therriault, J.-C., 2000. Trophic structure of macrobenthos in the Gulf of St. 501 Lawrence and on the Scotian Shelf. Deep-Sea Res. Part II 47, 663-697.

502 DFO, 2006. Impacts of trawl gears and scallop dredges on benthic habitats, populations and 503 communities. DFO Can. Sci. Advis. Sec. Sci. Advis. Rep. 2006/025.

504 DFO, 2010. Occurrence, susceptibility to fishing, and ecological function of corals, sponges, 505 and hydrothermal vents in Canadian waters. DFO Can. Sci. Advis. Sec. Sci. Advis. Rep. $5062010 / 041$.

507 Dormann, C. F., Schymanski, S. J., Cabral, J., Chuine, I., Graham, C., Hartig, F., Kearney, 508 M., Morin, X., Römermann, C., Schröder, B., Singer, A., 2012. Correlation and process in 509 species distribution models: brindging a dichotomy. J. Biogeogr. Special Issue.

510 Doubleday, W. G., 1981. Manual on groundfish surveys in the NAFO area (Revised). NAFO 511 Scientific Council Studies. 81/VI/7.

512 Dutil, J.-D., Proulx, S., Chouinard, P.-M., and Borcard, D., 2011. A hierarchical classification 513 of the seabed based on physiographic and oceanographic features in the St Lawrence. Can. 514 Tech. Rep. Fish. Aquat. Sci. 2916.

515 Gaston, G. R., 1987. Benthic polychaeta of the Middle Atlantic Bight: Feeding and 516 distribution. Mar. Ecol. Prog. Ser. 36, 251-262. 
517 Gilbert, D., Sundby, B., Gobeil, C., Mucci, A., Trembaly, G.-H., 2005. A seventy-two-year

518 record of diminishing deep-water oxygen in the St. Lawrence estuary: The northwest Atlantic 519 connection. Limnol. Oceanogr. 50, 1654-1666.

520 Gilbert, D., Chabot, D., Archambault, P., Rondeau, B., Hébert, S., 2007. Appauvrissement en 521 oxygène dans les eaux profondes du Saint-Laurent marin : causes possibles et impacts 522 écologiques. Nat. Can. 131, 67-75.

523 Glockzin, M., Zettler, M. L., 2008. Spatial macrozoobenthic distribution patterns in relation 524 to major environmental factors- A case study from the Pomeranian Bay (southern Baltic Sea). 525 J. Sea Res. 59, 144-161.

526 Guisan, A., Zimmermann, E., 2000. Predictive habitat distribution models in ecology. Ecol. 527 Model. 135, 147-186.

528 Guisan, A., Thuiller,W., 2005. Predicting species distribution: offering more than simple 529 habitat models. Ecol. Lett. 8, 993-1009.

530 Harris, C.K., Wiberg, P., 2002. Across-shelf sediment transport: Interactions between 531 suspended sediment and bed sediment. J.Geophys. Res. 107, 1-12.

532 Hirzel, A. H., Le Lay, G., Helfer, V., Randin, C., Guisan, A., 2006. Evaluating the ability of 533 habitat suitability models to predict species presences. Ecol. Model. 199, 142-152.

534 Houghton, R. W., Fairbanks, R. G., 2001. Water sources for Georges Bank. Deep-Sea Res. 535 Part II 48, 95-114.

536 Hutchinson, G. E., 1957. Concluding remarks, in: Cold Spring Harbor Symposia on 537 Quantitative Biology, Cold Spring Harbor, pp 415-427. 
538 Josefson, A.B., Conley, D.J., 1997. Benthic response to a pelagic front. Mar. Ecol. Prog. Ser. $539147,49-62$.

540 Koutitonsky, V. G., Bugden, G. L. 1991. The physical oceanography of the Gulf of St.

541 Lawrence: a review with emphasis on the synoptic variability of the motion. In J.-C.

542 Therriault (Editor), The Gulf of St. Lawrence: small ocean or big estuary? Can. Spec. Publ.

$543 \quad$ Fish. Aquat. Sci. 113, 57-90.

544 Labrune, C., Grémare, A., Amouroux, J.M., Sardà, R., Gil, J., Taboada, S., 2007. Assessment

545 of soft-bottom polychaete assemblages in the Gulf of Lions (NW Mediterranean) based on a 546 mesoscale survey. Est. Coast. Shelf Sci. 71, 133-147.

547 Labrune, C., Grémare, A., Amouroux, J.M., Sardà, R., Gil, J., Taboada, S., 2008. Structure

548 and diversity of shallow soft-bottom benthic macrofauna in the Gulf of Lions (NW

549 Mediterranean). Helgol. Mar. Res. 62, 201-214.

550 Le Fouest, V., 2005. Étude couplage circulation-production planctonique à méso-échelle dans

551 le Golfe du Saint-Laurent (Canada) via une approche par modélisation tridimensionnelle.

552 Thèse de Doctorat. Rimouski : Université du Québec à Rimouski. Département de biologie.

553 Legendre, P., Legendre, L., 1998. Numerical Ecology, Elsevier. Amsterdam.

554 Legendre, P., Gallagher, E.D., 2001. Ecologically meaningful transformations for ordination 555 of species data. Oecologia 129, 271-280.

556 Lévesque, M., 2009. Caractérisation de la macrofaune epibenhique de l'estuaire et du nord du 557 Golfe du Saint-Laurent (Québec-Canada) en relation avec les paramètres environnementaux : 558 analyses multivariées et approche de géostatistique. Master's thesis Université du Québec à 559 Rimouski, Rimouski (Québec). 
560 Loring, D. H., Nota, D. J. G. 1973. Morphology and sediment of the Gulf of St.Lawrence. J. 561 Fish. Res. Board Can. 182.

562 Martin C.S., Vaz S., Koubbi P., Meaden G.J., Engelhard G.H., Lauria V., Gardel L., Coppin

563 F., Delavenne J., Dupuis L., Ernande B., Foveau A., Lelievre S., Morin J., Warembourg C., 564 Carpentier A., 2010. A digital atlas helps to link the ontogenic shifts in fish spatial

565 distribution to the environment of the eastern English Channel. Dab Limanda limanda as a 566 case study. Cybium 34, 59-71.

567 Massad, R., Brunel, P., 1979. Associations par stations, densités et diversité des polychètes 568 du benthos circalittoral et bathyal de l'estuaire maritime du Saint-Laurent. Nat. Can. 106, $569229-253$.

570 Maurer, D., Leathem, W., 1981. Polychaete feeding guilds from Georges Bank, USA. Mar. 571 Biol. 62, 161-171.

572 McArthur, M. A., Brooke, B. P., Przeslawski, R., Ryan, D. A., Lucieer, V. L., Nichol, S., 573 McCallum, A. W., Mellin, C., Cresswell, I. D., Radke, L. C., 2010. On the use of abiotic 574 surrogates to describe marine benthic biodiversity. Est. Coast. Shelf Sci. 88, 21-32.

575 McCallum, B. R., Walsh, S. J., 2002. An update on the performance of the Campelen 1800 576 during the bottom trawl survey in NAFO subareas 2 and 3 in 2001 NAFO SCR Doc., No. 32, 577 Serial No. N4643.

578 McCullagh, P. Nedler, J. A., 1989. Generalized Linear Models, second ed. Chapman and 579 Hall, London. 
580 Mellin, C., Bradshaw, C. J. A., Meekan, M. G., Caley, M. J., 2010. Environmental and spatial 581 predictors of species richness and abundance in coral reef fishes. Glob. Ecol. Biogeogr. 19, $582 \quad 212-222$.

583 Mellin, C., Russel, B.D., Connell, S.D., Brook, B.W., Fordham, D.A., 2012. Geographic 584 range determinants of two commercially important marine mollucs. Diversity Distrib. 18, 585 133-146.

586 Messieh, S.N., Rowell, T.W., Peer, D.L., Cranford, P.J., 1991. The effects of trawling, 587 dredging and ocean dumpling on the esatern Canadian continental shelf seabed. Cont. Shelf $588 \quad$ Res. 11, 1237-1263.

589 Mucci, A., Starr, M., Gilbert, D., Sundby, B., 2011. Acidification of Lower St. Lawrence 590 Estuary bottom waters. Atm. Ocean 49, 206-218.

591 Newell, R. C., Seiderer, L. J., Hitchcock, D. R., 1998. The impact of dredging works in 592 coastal waters: a review of the sensitivity to disturbance and subsequent recovery of 593 biological resources on the sea bed. Oceanogr. Mar. Biol. 36, 127-178.

594 Oksanen, J., 2011. vegan: Community Ecology Package. R package version 1.17-10. 560 595 (http://CRAN-R-project.org/package=vegan).

596 Ouellet, G., 1982. Étude de l'interaction des animaux benthiques avec les sédiments du 597 Chenal Laurentien. Master’s thesis Université du Québec à Rimouski, Rimouski (Québec). 598 Pastor, L., Deflandre, B., Voillier, E., Cathalot, C., Metzger, E., Rabouille, C., Escoubeyrou, 599 K., Lloret, E., Pruski, A. M., Vétion, G., Desmalades, M., Buscail, R., Grémare, A., 2011. 600 Influence of the organic matter composition on benthic oxygen demand in the Rhône River 601 prodelta (NW Mediterranean Sea). Cont. Shelf Res. 31, 1008-1019. 
602 Peer, D. L, 1963. A preliminary study of the composition of benthic communities in the Gulf 603 of St. Lawrence. Manuscript Report Series (Oceanogr. and Limnological). Atl. Oceanogr. 604 Group 145, 1-24.

605 Préfontaine, G., Brunel, P., 1962. Liste d'invertébrés marins recueillis dans l'estuaire du 606 Saint-Laurent de 1929 à 1934. Nat. Can. 89, 237-263.

607 R Core Development Team. R: A language and Environment for Statistical Computing 608 (http://www.P-project.org) 2011.

609 Rabaut, M., Guilini, K., Van Hoey, G., Vincx, M., Degraer, S., 2007. A bio-engineered soft610 bottom environment: The impact of Lanice conchilega on the benthic species-specific 611 densities and community structure. Est. Coast. Shelf Sci. 75, 525-536.

612 Robert, G., 1979. Benthic molluscan fauna of the St. Lawrence estuary and its ecology as 613 assessed by numerical methods. Nat. Can. 106, 211-227.

614 Rose, G. A., Leggett, W. C., 1988. Hydroacoustic signal classification of fish schools by 615 species. Can. J. Fish. Aquat. Sci. 45, 597-604.

616 Rosenberg, R., 1995. Benthic marine fauna structured by hydro-dynamic processes and food 617 availability. Neth. J. Sea Res. 34, 303-317.

618 Sainte-Marie, B., Dufour, R., Bourassa, L., Chabot, D., Dionne, M., Gilbert, D., Rondeau, A., 619 Sévigny, J.-M., 2005. Criteria and proposition for the definition of snow crab (Chionoecetes 620 opilio) production units in the estuary and northern Gulf of St. Lawrence. Secrétariat 621 canadien de consultation scientifique du MPO. Document de Recherche. 2005/059.

622 Saucier, J-.F., Roy, F., Gilbert, D., Pellerin, P., Ritchie, H., 2003. Modelling the formation 623 and circulation processes of water masses and sea ice in the Gulf of St. Lawrence, Canada. $J$. 
624 Geophys. Res. 108(C8), 3269.

625 Swain, D.P., 1999. Changes in the distribution of Atlantic cod (Gadus morhua) in the 626 southern Gulf of St. Lawrence - effects of environmental change or change in environmental 627 preferences? Fish. Oceanogr. 8, 1-17.

628 Thistle, D., Yingst, J.Y., Fauchald, K., 1985. A deep-sea benthic community exposed to

629 strong near-bottomcurrents on the Scotian Rise (western Atlantic). Mar. Geol. 66, 91-112.

630 Thorson, G., 1971. Life in the Sea. McGraw-Hill, New York.

631 Urbanski, J. A., Szymelfenig, M., 2003. GIS-based mapping of benthic habitats. Est. Coast. 632 Shelf Sci. 56, 99-109.

633 Vaz S., ter Hofstede, R., Martin, J., Dewarumez, J.-M., Verin, Y., Le Roy, D., Heessen, H., 634 Daan, N., 2007. Benthic invertebrate community structure inferred from bottom trawl hauls 635 observations and its relationships to abiotic conditions in the southern North Sea. ICES CM 636 2007/A:01, Helsinki.

637 Vaz S., Carpentier A., Coppin, F., 2008. Modelling fish community habitat in the Eastern 638 English Channel: tentative prediction of habitat distribution change under different climatic 639 variation scenarios. ICES Annual Science Conference, Halifax (Canada), 20-26 septembre. 640 Communication.

641 Ward, J.H., 1963. Hierarchical grouping to optimize an objective function. J. Am. Stat. Assoc. $64258,236-244$.

643 Wenger, S.J., Olden, J.D., 2012. Assessing transferability of ecological models: an 644 underappreciated aspect of statistical validation. Meth. Ecol. Evol. 3, 260-267. 
Table 1. EGSL environmental variables used in the analyses. Abbreviations (in alphabetical order) are given only for the variables selected after the variable-reduction procedure.

\begin{tabular}{lclc}
\hline $\begin{array}{l}\text { Quantitative and binary (*) } \\
\text { environmental variables }\end{array}$ & Abbreviation & $\begin{array}{l}\text { Qualitative environmental variables } \\
\text { (sediment types) }\end{array}$ & Abbreviation \\
\hline Bottom current & BC & Pelite & 1 \\
Depth & D & Sandy pelite & $1 \mathrm{a}$ \\
Distance to coast & DC & Calcareous pelite & $1 \mathrm{~b}$ \\
Oxygen saturation & $\mathrm{O}$ & Gravely-sandy pelite + calcareous rocks & $1 \mathrm{c}$ \\
Seabed relief uniformity & $\mathrm{U}$ & Very-sandy and gravely-sandy pelite & $1 \mathrm{e}$ \\
Slope & $\mathrm{S}$ & Well-sorted and fine sand & 2 \\
Surface of protected (sheltered) area & $\mathrm{P}$ & Fine clayish sand & $2 \mathrm{a}$ \\
Temperature & $\mathrm{T}$ & Poorly-sorted pelitic sand & $2 \mathrm{~b}$ \\
Salinity & & Sand and mid-coarse grains & $2 \mathrm{c}$ \\
Surface of exposed and surface of & & Gravely-pelitic reworked sand with & $2 \mathrm{~d}$ \\
semi-exposed area & & poorly-sorted gravely sand & \\
Surface of: hollows; bumps & & Poorly-sorted gravely sand & $2 \mathrm{e}$ \\
Belongs to: channel; continental & & Calcarenite + gravel with occasional & 3 \\
shelf; bank $\left.*^{*}\right)$ & & sand parcels & \\
Latitude & & Gravel & 4 \\
Longitude & & Brown-red ice-age rocks & 5 \\
& & & \\
\hline
\end{tabular}


Table 2. List of benthic community groups including mean depth and number of taxa for each group. The five dominant taxa in terms of biomass and their respective frequency of occurrence within the given group are indicated.

\begin{tabular}{|c|c|c|c|c|}
\hline Group & $\begin{array}{l}\text { Mean } \\
\text { depth (m) }\end{array}$ & $\begin{array}{l}\text { Species } \\
\text { richness }\end{array}$ & Dominant species & $\begin{array}{l}\text { Frequency of } \\
\text { occurrence }(\%)\end{array}$ \\
\hline \multirow[t]{6}{*}{ A } & 116 & 177 & Actiniaria & 69 \\
\hline & & & Pandalus montagui & 93 \\
\hline & & & Pandalus borealis & 46 \\
\hline & & & Ophiura sarsii & 24 \\
\hline & & & Porifera & 67 \\
\hline & & & Ctenodiscus crispatus & 46 \\
\hline \multirow[t]{6}{*}{ B } & 273 & 72 & Actiniaria & 100 \\
\hline & & & Pandalus montagui & 20 \\
\hline & & & Brisaster fragilis & 98 \\
\hline & & & Ctenodiscus crispatus & 100 \\
\hline & & & Ophiura sarsii & 73 \\
\hline & & & Pennatulacea & 91 \\
\hline \multirow[t]{6}{*}{$\mathrm{C}$} & 303 & 135 & Pandalus borealis & 99 \\
\hline & & & Pennatulacea & 75 \\
\hline & & & Pasiphaea multidentata & 82 \\
\hline & & & Actiniaria & 74 \\
\hline & & & Brisaster fragilis & 63 \\
\hline & & & Ctenodiscus crispatus & 67 \\
\hline \multirow[t]{6}{*}{$\mathrm{D}$} & 239 & 120 & Pandalus borealis & 100 \\
\hline & & & Actiniaria & 82 \\
\hline & & & Pandalus montagui & 23 \\
\hline & & & Pennatulacea & 62 \\
\hline & & & Pasiphaea multidentata & 53 \\
\hline & & & Brisaster fragilis & 52 \\
\hline \multirow[t]{6}{*}{$\mathrm{E}$} & 268 & 100 & Pandalus borealis & 100 \\
\hline & & & Actiniaria & 78 \\
\hline & & & Pennatulacea & 69 \\
\hline & & & Brisaster fragilis & 66 \\
\hline & & & Porifera & 56 \\
\hline & & & Pasiphaea multidentata & 67 \\
\hline \multirow[t]{6}{*}{$\mathrm{F}$} & 288 & 105 & Pandalus borealis & 100 \\
\hline & & & Actiniaria & 73 \\
\hline & & & Pennatulacea & 71 \\
\hline & & & Porifera & 54 \\
\hline & & & Pasiphaea mutlidentata & 72 \\
\hline & & & Alcyonacea & 29 \\
\hline
\end{tabular}


Table 3. Results from redundancy analysis (RDA) using megafauna biomass and environmental data from 2006-2009, depicting relationships between species and environment resulting from the first two RDA axes. P-values were given from permutation tests (999 permutations, $* * *:<0.001)$. See Table 1 for environmental variable abbreviations.

\begin{tabular}{|c|c|c|c|c|}
\hline & Axis 1 & Axis 2 & & \\
\hline Eigenvalues & 0.14 & 0.03 & & \\
\hline Variance explained & 0.68 & 0.13 & & \\
\hline $\begin{array}{l}\text { Species-environment } \\
\text { correlations }\end{array}$ & 0.85 & 0.66 & & \\
\hline \multirow{2}{*}{\multicolumn{3}{|c|}{$\begin{array}{l}\text { Correlations with } \\
\text { environmental variables }\end{array}$}} & \multicolumn{2}{|c|}{ Conditional effects } \\
\hline & & & $\mathrm{P}$ & $\mathrm{R}^{2}$ \\
\hline $\mathrm{BC}$ & -0.978 & $\begin{array}{l}-0.21 \\
\end{array}$ & **** & 0.14 \\
\hline $\mathrm{D}$ & 0.903 & -0.429 & $* * *$ & 0.67 \\
\hline DC & 0.999 & -0.021 & $* * *$ & 0.15 \\
\hline $\mathrm{O}$ & -0.985 & 0.173 & $* * *$ & 0.61 \\
\hline $\mathrm{U}$ & 0.981 & -0.193 & $* * *$ & 0.08 \\
\hline$S$ & 0.419 & -0.908 & & $5.10^{-4}$ \\
\hline $\mathrm{P}$ & -0.999 & 0.005 & & $5.10^{-3}$ \\
\hline \multirow[t]{2}{*}{$\mathrm{T}$} & 0.996 & -0.092 & $* * *$ & 0.64 \\
\hline & & & $* * *$ & 0.26 \\
\hline 1 & 0.113 & 0.021 & $* * *$ & \\
\hline $1 \mathrm{a}$ & 0.067 & -0.034 & $* * *$ & \\
\hline $1 b$ & 0.136 & -0.021 & $* * *$ & \\
\hline $1 \mathrm{c}$ & -0.19 & 0.094 & $* * *$ & \\
\hline $1 \mathrm{e}$ & -0.035 & 0.149 & $* * *$ & \\
\hline 2 & 0.151 & -0.015 & $* * *$ & \\
\hline $2 a$ & 0.082 & -0.157 & $* * *$ & \\
\hline $2 b$ & 0.027 & 0.228 & $* * *$ & \\
\hline $2 c$ & -0.115 & 0.045 & $* * *$ & \\
\hline $2 d$ & -0.244 & 0.013 & $* * *$ & \\
\hline $2 \mathrm{e}$ & -0.314 & -0.007 & $* * *$ & \\
\hline 3 & -0.286 & -0.118 & $* * *$ & \\
\hline 4 & -0.332 & -0.107 & $* * *$ & \\
\hline 5 & 0.137 & -0.036 & $* * *$ & \\
\hline
\end{tabular}


Table 4. Statistics (adjusted $\mathrm{R}^{2}$, area under the ROC curve (AUC), estimates, and p-values: $* * *<0.001, * *<0.01, *<0.5)$ of GLMs predicting the presence of each group according to environmental variables used in RDA (see Table 3). See Table 1 for environmental variable abbreviations.

\begin{tabular}{|c|c|c|c|c|c|c|}
\hline Group & $\mathrm{A}$ & B & $\mathrm{C}$ & $\mathrm{D}$ & $E$ & $\mathrm{~F}$ \\
\hline Adj. $R^{2}$ & 0.59 & 0.80 & 0.44 & 0.42 & 0.49 & 0.42 \\
\hline AUC & 0.95 & 0.95 & 0.85 & 0.83 & 0.80 & 0.77 \\
\hline Intercept & -3.314 & 5.222 & $-9.368 * * *$ & $3.740 *$ & 0.377 & $-9.732^{* * * *}$ \\
\hline $\mathrm{BC}$ & 1.789 & 0.998 & -1.947 & -2.247 & -0.079 & 0.871 \\
\hline $\mathrm{P}$ & 0.699 & -0.963 & -0.392 & -0.285 & -7.984 & -502.526 \\
\hline DC & $-1.89 .10^{-6}$ & $-4.02 .10^{-5} *$ & $1.98 .10^{-5 * *}$ & $-3.86 .10^{-6}$ & $5.64 .10^{-6}$ & $-1.24 .10^{-6}$ \\
\hline $\mathrm{D}$ & $-0.008 * * *$ & 0.000 & $0.014 * * *$ & $-0.010 * * *$ & $-0.008 * *$ & 0.002 \\
\hline$S$ & 0.458 & 1.121 & $1.914 * * *$ & -0.975 & $-1.973 *$ & -0.838 \\
\hline U & 1.953 & 4.302 & -0.343 & -1.913 & -2.419 & -1.175 \\
\hline $\mathrm{O}$ & $0.055^{* * *}$ & $-0.140 * * *$ & $0.039 * * *$ & $-0.039 * * *$ & $-0.042 * *$ & $0.040 * *$ \\
\hline $\mathrm{T}$ & -0.358 & $-1.462 * *$ & 0.105 & $0.636 * *$ & $0.857^{*}$ & $1.432^{* * * *}$ \\
\hline $1 \mathrm{a}$ & 0.035 & 0.954 & $1.228 * * *$ & $-1.513 * * *$ & 0.581 & 0.396 \\
\hline $1 \mathrm{~b}$ & -0.691 & 0.029 & 0.014 & $-1.000^{* *}$ & $1.362 * * *$ & $1.197 * *$ \\
\hline $1 \mathrm{c}$ & 0.655 & -15.631 & 0.431 & -0.668 & -14.410 & 0.556 \\
\hline $1 \mathrm{e}$ & 0.578 & -16.159 & 0.711 & $-1.211 * *$ & 0.410 & 0.475 \\
\hline 2 & -16.342 & -15.172 & 21.959 & -20.180 & -17.444 & -18.767 \\
\hline $2 \mathrm{a}$ & -15.406 & -15.118 & $2.796 *$ & -20.024 & -16.496 & 1.408 \\
\hline $2 b$ & 0.407 & -16.282 & 1.154 & -1.508 & -0.502 & $1.865^{*}$ \\
\hline $2 \mathrm{c}$ & $-2.535^{*}$ & -15.087 & -13.704 & 1.951 & -13.377 & -17.248 \\
\hline $2 d$ & $1.697^{* *}$ & -16.527 & 0.590 & -18.302 & -0.849 & -0.182 \\
\hline $2 \mathrm{e}$ & 15.618 & -15.774 & -13.531 & -18.120 & -13.800 & -19.146 \\
\hline 3 & 1.758 & -16.774 & 1.064 & -18.283 & -13.968 & -17.320 \\
\hline 4 & 13.244 & -16.761 & -11.336 & -15.216 & -13.003 & -15.675 \\
\hline 5 & -15.993 & -13.662 & 1.950 & -1.423 & -17.129 & 1.510 \\
\hline
\end{tabular}


Figure 1. Estuary and Northern Gulf of St. Lawrence map showing the location of trawl stations (grey crosses) for years 2006-2009. Bathymetric lines delineate deep channels (depth > $200 \mathrm{~m}$ ).

Figure 2. Epibenthic megafaunal communities in the EGSL in August 2006-2009: (a) Cluster tree (Ward distance) based on Bray-Curtis dissimilarity matrix using species biomass data; (b) Non-metric multidimensional scaling (nMDS) ordination based on Hellinger-standardized biomass data, using Euclidean distance. A specific symbol was attributed to each cluster identified on the tree (groups A to F).

Figure 3. Location of the 6 communities in the EGSL, as determined by hierarchical cluster analysis on epibenthic fauna biomass data (graph labels correspond to group labels A to F).

Figure 4. RDA ordination diagram of 755 epibenthic fauna sampling stations for years 20062009, obtained using Hellinger-standardized biomass data. The quantitative environmental variables used in the RDA (shown as vectors) were selected using PCA and analysis of the correlation matrix from a bigger set of variables. Sediment types, included as factors (qualitative variable), are represented by open circles. See Table 1 for environmental variable abbreviations.

Figure 5. Habitat suitability maps (probability of presence) for epibenthic megafauna communities in the EGSL, using GLMs (graph labels correspond to group labels A to F).

Figure A.1. Maps of bottom environmental conditions for years 2006-2009: (a) depth (m), (b) oxygen (\% saturation), (c) temperature $\left({ }^{\circ} \mathrm{C}\right),(\mathrm{d})$ maximal bottom current $(\mathrm{cm} / \mathrm{sec}),(\mathrm{e})$ seabed relief (proportion of uniformity), (f) distance to the coast (m). 


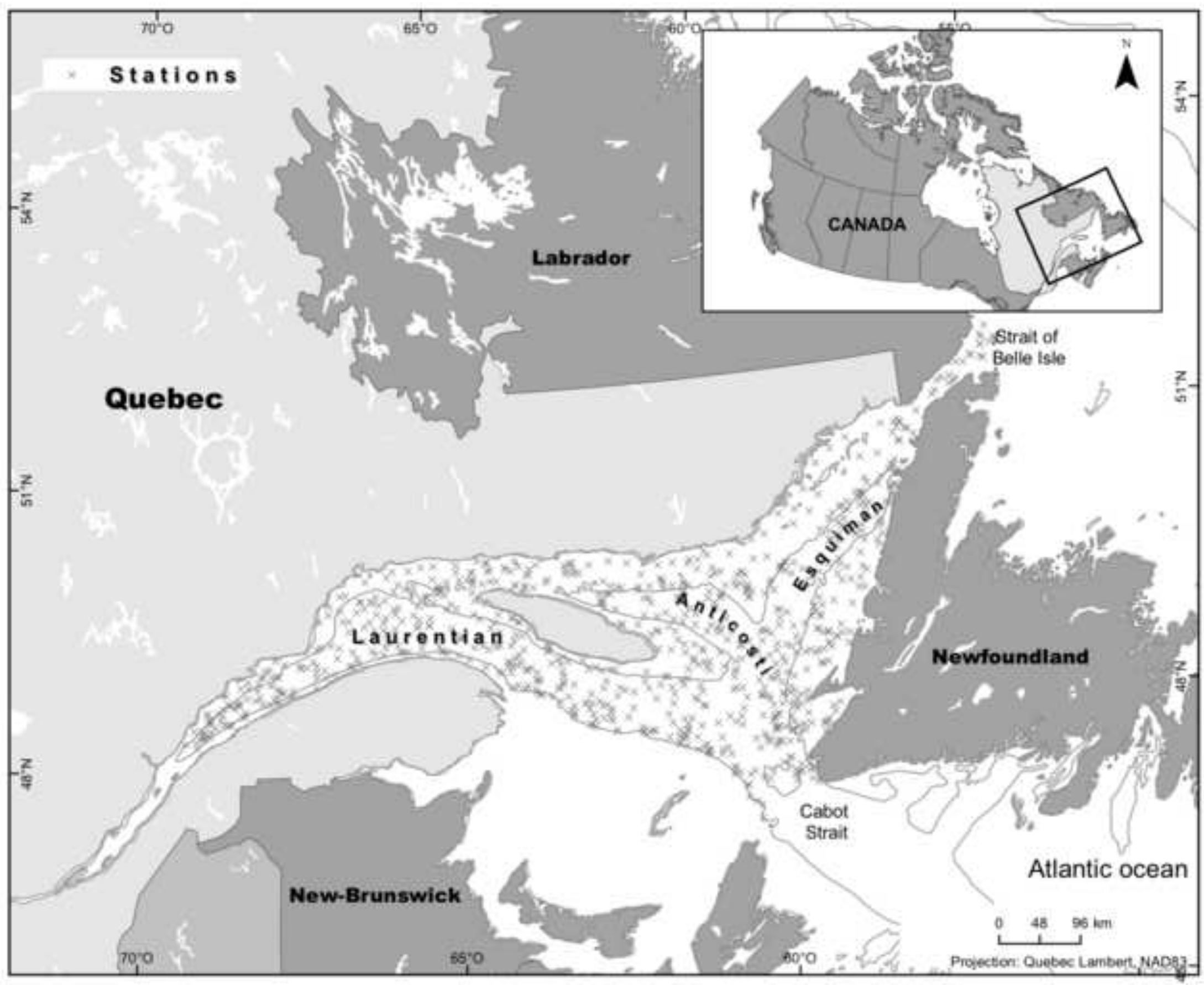




\section{Figure(s)}

Click here to download high resolution image

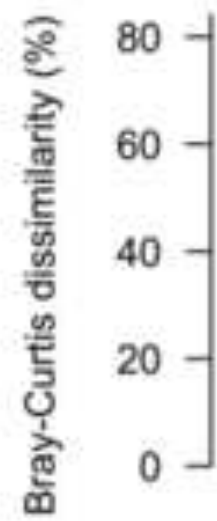
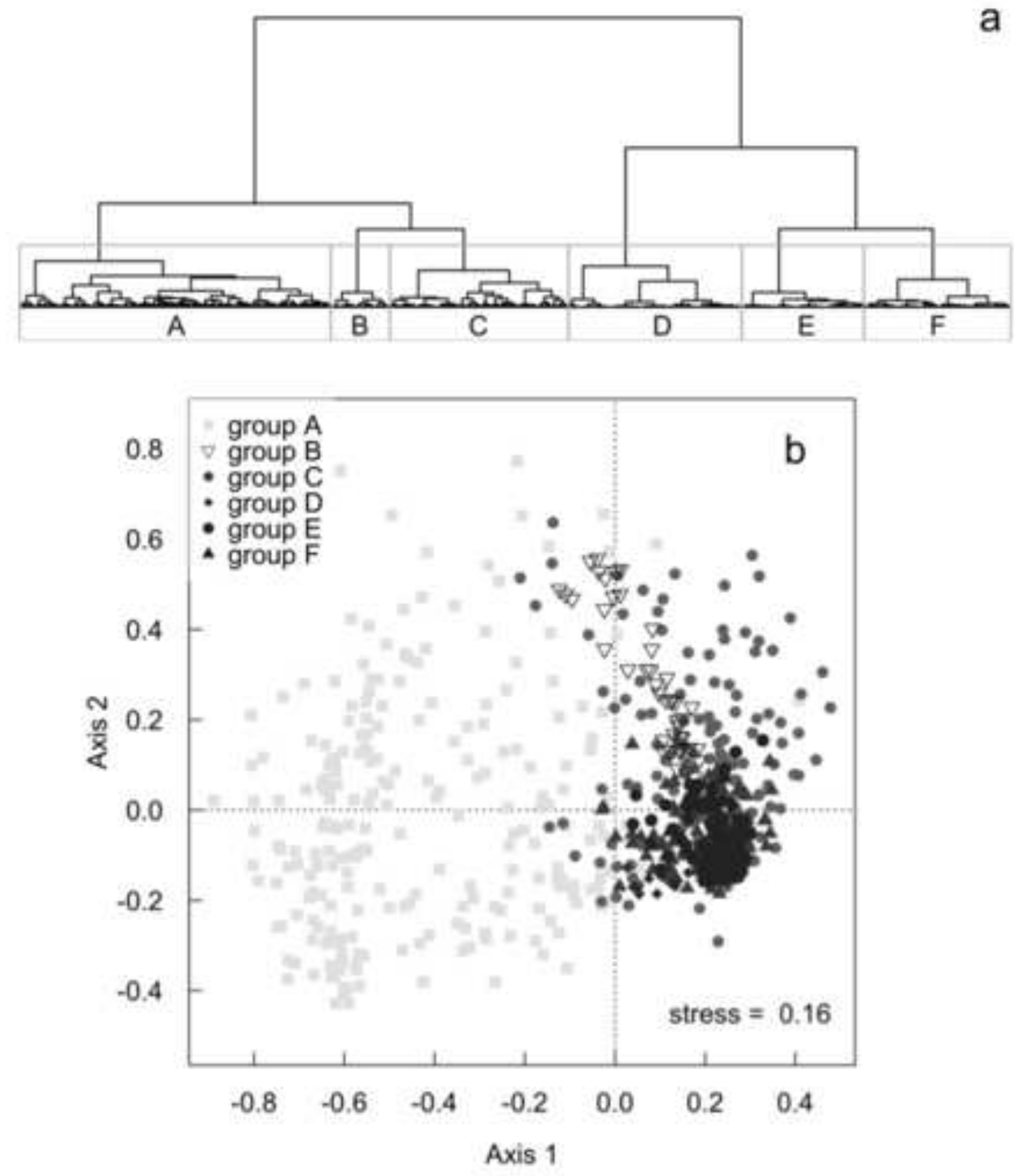

a 

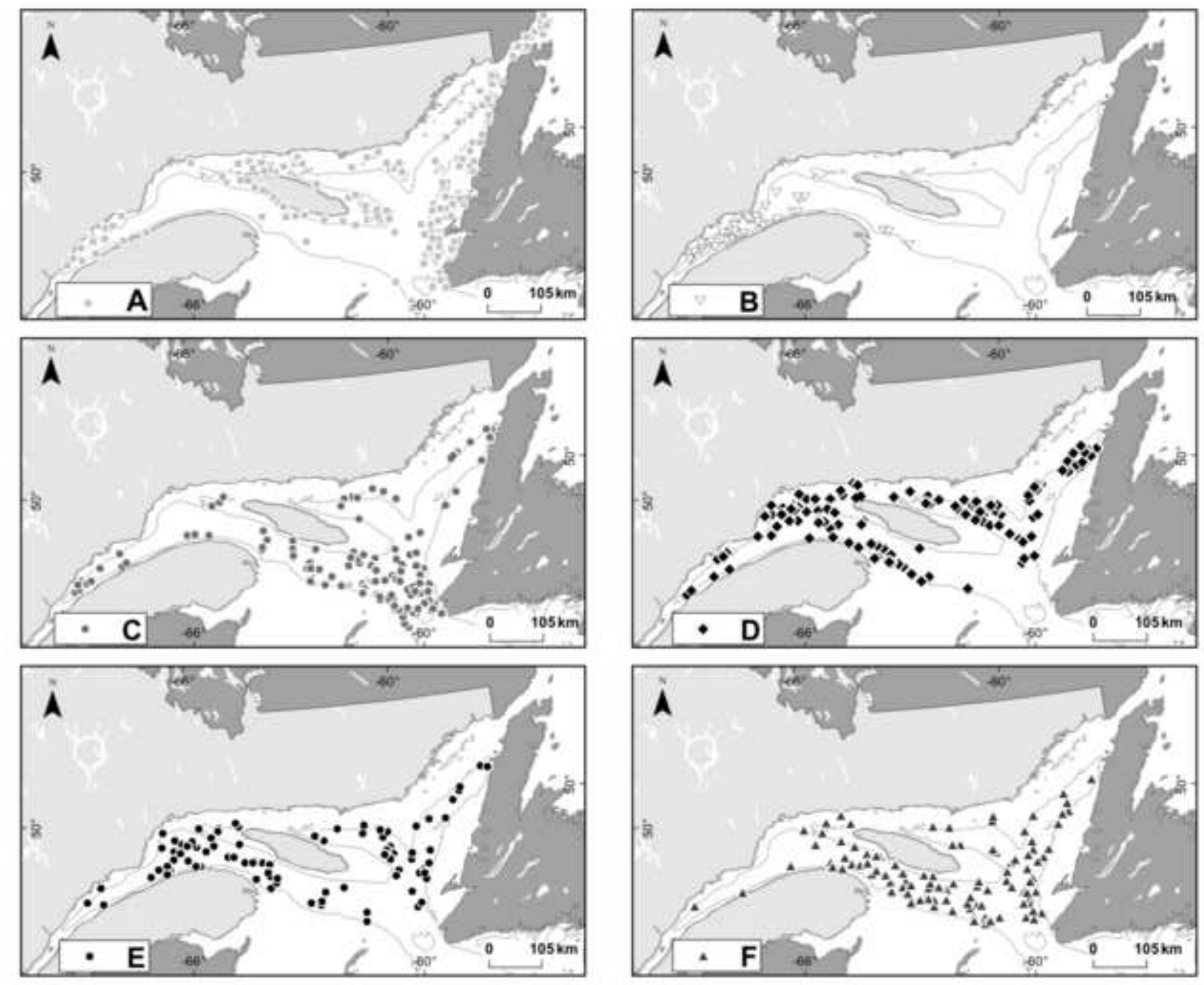

Figure(s)
Click here to download high resolution image 
Figure(s)
Click here to download high resolution image

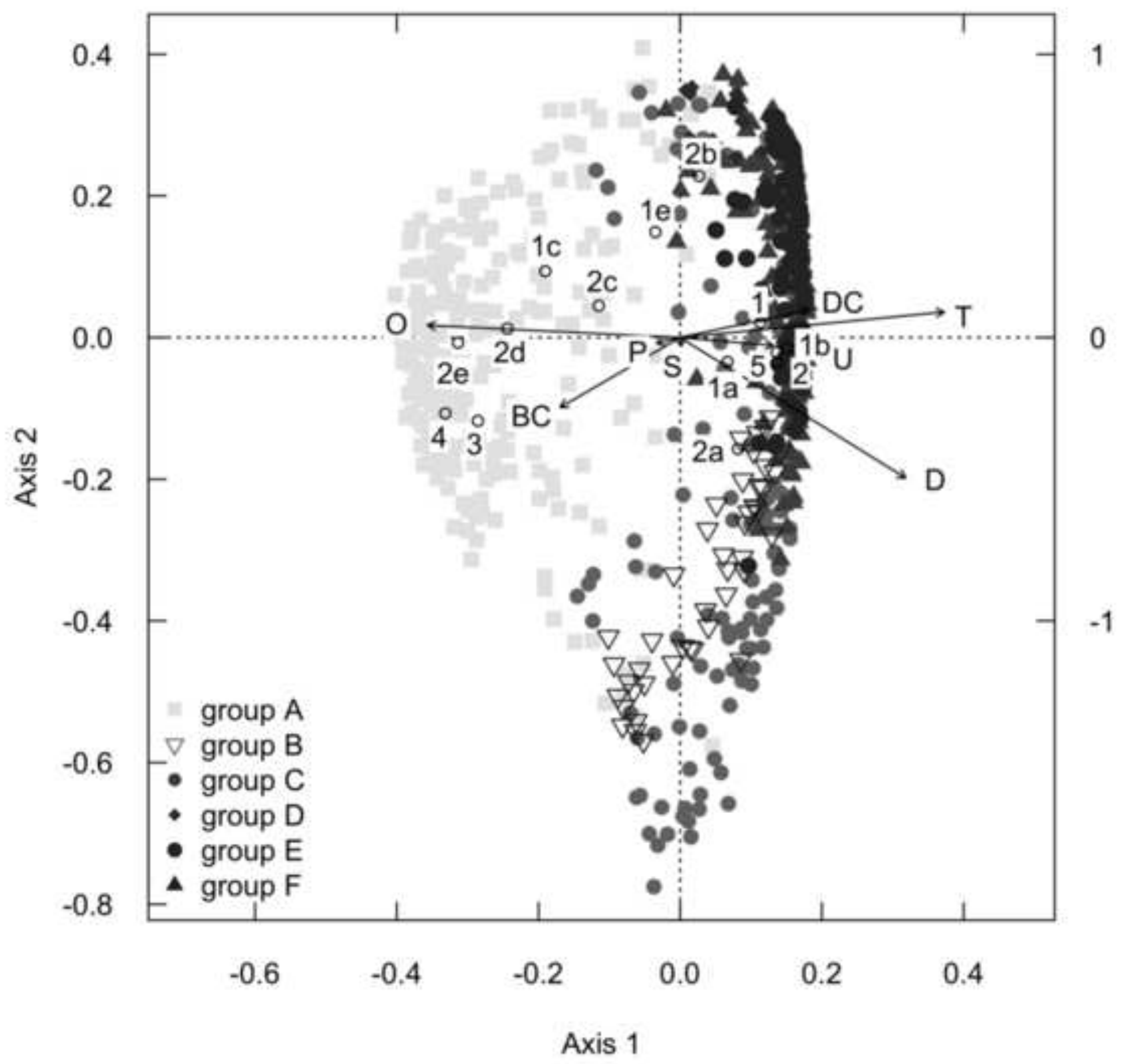



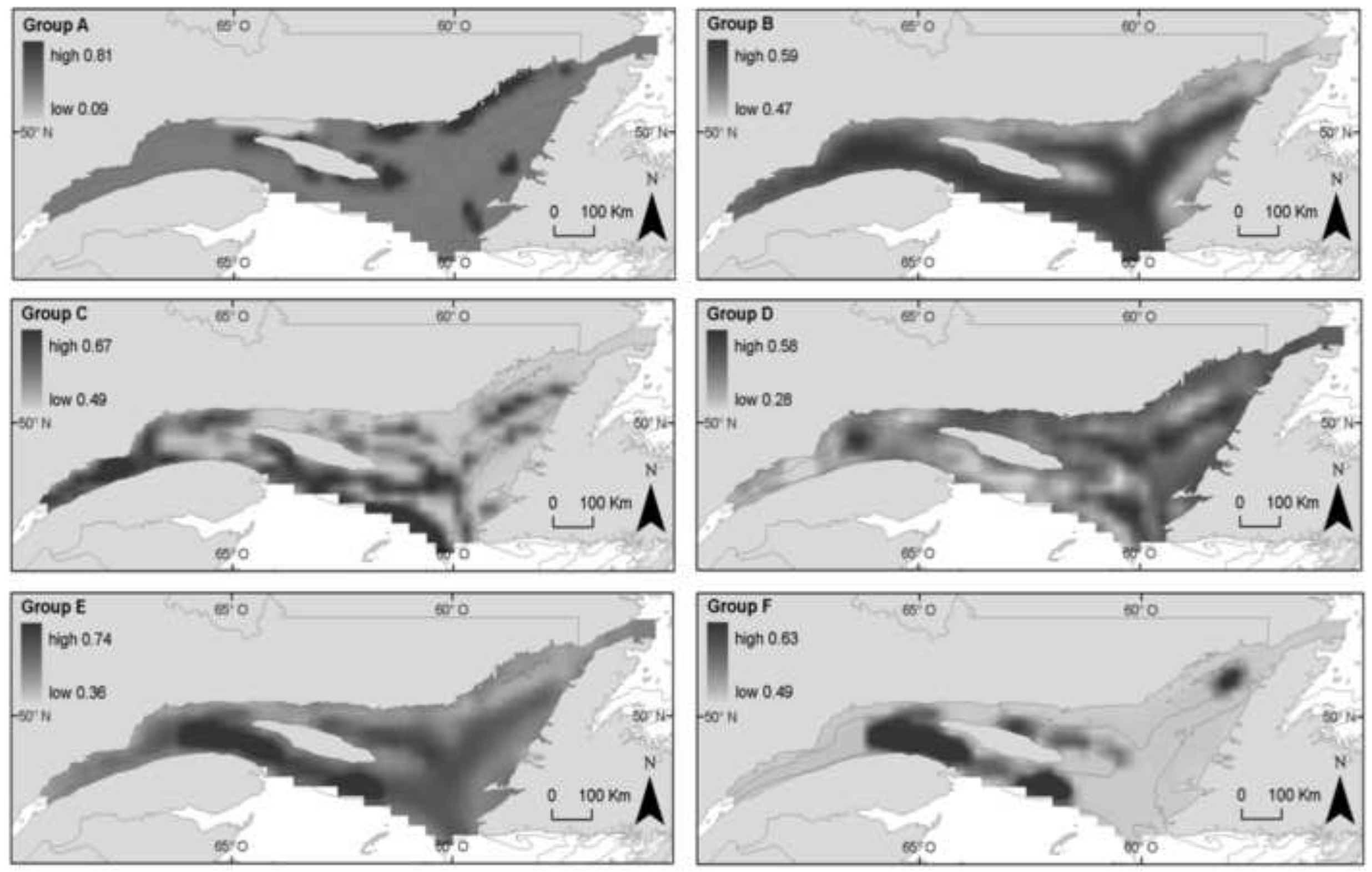